\title{
Temperature-Dependent Dynamics of Giant Vesicles Containing Hydrolysable Lipids Having an Amide Linkage
}

\author{
Maito Tameyuki ${ }^{1}$, Hisato Hiranaka ${ }^{1}$, Taro Toyota ${ }^{2}$, Kouichi Asakura $^{1}$, Taisuke Banno ${ }^{1 *}$ \\ ${ }^{1}$ Department of Applied Chemistry, Faculty of Science and Technology, Keio University, 3-14-1 \\ Hiyoshi, Kohoku-ku, Yokohama 223-8522, Japan \\ ${ }^{2}$ Department of Basic Science, Graduate School of Arts and Sciences, The University of Tokyo, \\ 3-8-1 Komaba, Meguro-ku, Tokyo 153-8902, Japan
}

Supporting Information Index

Synthetic procedures

... p. 2

Figures

...p. 9

Table

... p. 18

Reference

...p. 18 


\section{Synthetic procedures}

\section{Synthesis of the amphiphile having a methacryloyl group (MEs)}

MEs was synthesized according to our previous paper as shown in Scheme S1 ${ }^{1}$.<smiles>C=C(C)C(=O)Cl</smiles>
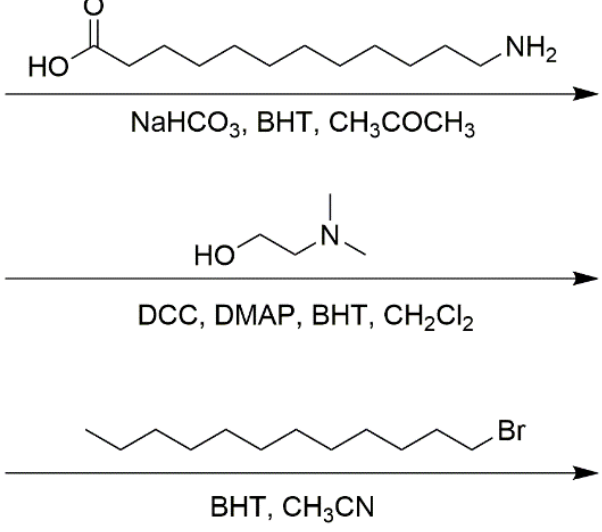<smiles>C=C(C)C(=C)N[14C](=[14CH])C(=O)O</smiles>

MCar<smiles>C=C(C)C(=O)NC(=O)OCCN(C)C</smiles><smiles>C=C(C)C(=O)NC(=O)OCC[N+](C)(C)C(Br)(Br)Br</smiles>

Scheme S1. Synthesis of MEs having polymerisable and hydrolysable groups.

Synthesis of 12-(methacryloylamino)dodecanoic acid (MCar)

A mixture of 12-aminododecanoic acid (2.58 g, $12 \mathrm{mmol})$, methacryloyl chloride (3.14 g, 24 mmol), sodium hydrogen carbonate (2.02 g, $24 \mathrm{mmol})$ and 2,6-di-tert-butyl-p-cresol (60 $\mathrm{mg})$ as an inhibitor was stirred in anhydrous acetone $(60 \mathrm{~mL})$ at $70{ }^{\circ} \mathrm{C}$ for $1 \mathrm{~h}$. After the reaction, the mixture was poured on water $(100 \mathrm{~mL})$, and the precipitate was obtained as a crude product. Purification was carried out by recrystallization using ethyl acetate $(20 \mathrm{~mL})$ to obtain MCar, at a $53 \%$ yield $(1.80 \mathrm{~g})$, as a white crystal.

${ }^{1} \mathrm{H}$ NMR $\left(400 \mathrm{MHz}, \mathrm{CDCl}_{3}\right) \delta 5.65(\mathrm{~s}, 1 \mathrm{H}), 5.30(\mathrm{~s}, 1 \mathrm{H}), 3.35-3.22(\mathrm{~m}, 2 \mathrm{H}), 2.33(\mathrm{t}, J=7.4 \mathrm{~Hz}$, 2H), $1.95(\mathrm{~s}, 3 \mathrm{H}), 1.70-1.43(\mathrm{~m}, 4 \mathrm{H}), 1.36-1.21(\mathrm{~m}, 14 \mathrm{H})$. ESI-MS in acetonitrile $(\mathrm{m} / \mathrm{z}): 284.2226$ $[\mathrm{M}+\mathrm{H}]^{+}$. Calcd, $284.2226[\mathrm{M}+\mathrm{H}]^{+}$. 
Synthesis of 12-(methacryloylamino) lauroyloxyethyl-N,N-dimethylamine (1)

A mixture of MCar (442 mg, $1.6 \mathrm{mmol})$, 2-dimethylamino ethanol (250 mg, $2.8 \mathrm{mmol}), 4$ dimethylamino pyridine $(8 \mathrm{mg})$ and 2,6-di-tert-butyl-p-cresol $(8 \mathrm{mg})$ was dissolved in anhydrous dichloromethane $(2.0 \mathrm{~mL})$. At $0{ }^{\circ} \mathrm{C}$, a dichloromethane solution $(1.0 \mathrm{~mL})$ of $N, N^{\prime}-$ dicyclohexylcarbodiimide ( $365 \mathrm{mg}, 1.8 \mathrm{mmol}$ ) was added, and the reaction mixture was stirred at $0{ }^{\circ} \mathrm{C}$ for $30 \mathrm{~min}$ and then at room temperature for $2 \mathrm{~h}$. After the reaction, the precipitate was filtered off, and the solvent was evaporated under reduced pressure. The residue was then purified by silica gel column chromatography [chloroform/methanol/triethylamine $=100 / 15 / 1$ (by volume), $R_{\mathrm{f}}=0.59$ ] to obtain 1 , at a $54 \%$ yield ( $305 \mathrm{mg}$ ), as a pale yellow syrup.

${ }^{1} \mathrm{H}$ NMR (400 MHz, $\left.\mathrm{CDCl}_{3}\right) \delta 5.67-5.60(\mathrm{~m}, 1 \mathrm{H}), 5.32-5.25(\mathrm{~m}, 1 \mathrm{H}), 4.15(\mathrm{t}, J=5.8 \mathrm{~Hz}, 2 \mathrm{H})$, 3.33-3.25 (m, 2H), $2.54(\mathrm{t}, J=5.6 \mathrm{~Hz}, 2 \mathrm{H}), 2.37-2.22(\mathrm{~m}, 8 \mathrm{H}), 1.95(\mathrm{~s}, 3 \mathrm{H}), 1.66-1.46(\mathrm{~m}, 4 \mathrm{H})$, $1.36-1.18(\mathrm{~m}, 14 \mathrm{H})$.

Synthesis of 12-(methacryloylamino)lauroyloxyethyl-N-dodecyl-N,N-dimethylammonium bromide (MEs)

The quaternarization of 1 (305 mg, $0.86 \mathrm{mmol}$ ) was carried out using 1-bromododecane (243 mg. $1.0 \mathrm{mmol})$ in the presence of 2,6-di-tert-butyl-p-cresol $(20 \mathrm{mg})$ in anhydrous acetonitrile $(1.6 \mathrm{~mL})$ at $65^{\circ} \mathrm{C}$ for $1 \mathrm{~d}$ with stirring. After the reaction, the solvent was evaporated under reduced pressure. Purification was carried out by reprecipitation from chloroform $(2 \mathrm{~mL})$ and ethyl acetate $(6 \mathrm{~mL})$ to obtain MEs (123 mg, 24\% yield) as a white crystal.

${ }^{1} \mathrm{H}$ NMR $\left(500 \mathrm{MHz}, \mathrm{MeOD}-d_{4}\right) \delta 5.64(\mathrm{~d}, J=1.2 \mathrm{~Hz}, 1 \mathrm{H}), 5.33(\mathrm{~d}, J=1.2 \mathrm{~Hz}, 1 \mathrm{H}), 4.55-4.45$ (m, 2H), 3.72-3.65 (m, 2H), 3.42-3.34 (m, 2H), $3.19(\mathrm{t}, J=7.5 \mathrm{~Hz}, 2 \mathrm{H}), 3.14(\mathrm{~s}, 6 \mathrm{H}), 2.37(\mathrm{t}, J$ $=7.5 \mathrm{~Hz}, 2 \mathrm{H}), 1.91(\mathrm{~s}, 3 \mathrm{H}), 1.85-1.74(\mathrm{~m}, 2 \mathrm{H}), 1.68-1.57(\mathrm{~m}, 2 \mathrm{H}), 1.56-1.45(\mathrm{~m}, 2 \mathrm{H}), 1.43-1.21$ (m, 32H), $0.88(\mathrm{t}, J=7.0 \mathrm{~Hz}, 3 \mathrm{H})$. ESI-MS in acetonitrile $(\mathrm{m} / \mathrm{z}): 523.4839\left[\mathrm{M}-\mathrm{Br}^{-}\right]^{+}$; calcd, 
$523.4833\left[\mathrm{M}-\mathrm{Br}^{-}\right]^{+}$.

\section{Synthesis of the amphiphile having an ester linkage (Es)}

LA was synthesized according to the procedure given in Scheme S2.

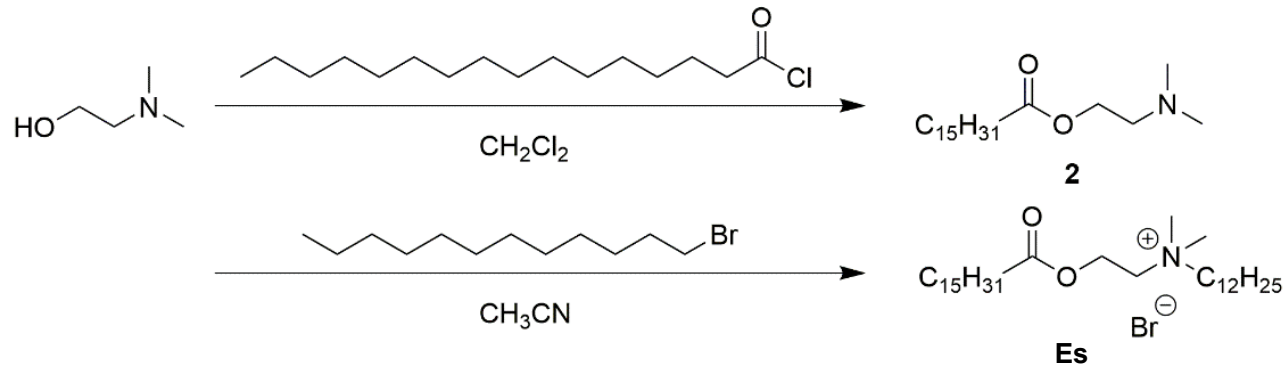

Scheme S2. Synthesis of Es having hydrolysable segments.

Synthesis of palmitoyloxyethyl-N,N-dimethylamine (2)

$N, N$-dimethylaminoethanol $(464 \mathrm{mg}, 5.2 \mathrm{mmol})$ in dichloromethane $(1.0 \mathrm{~mL})$ was added dropwise to a dichloromethane solution $(1.5 \mathrm{~mL})$ of palmitoyl chloride $(715 \mathrm{mg}, 2.6 \mathrm{mmol})$. The reaction mixture was stirred at room temperature for $4 \mathrm{~h}$. The mixture was then concentrated under reduced pressure, and the residue was dissolved in chloroform $(10 \mathrm{~mL})$. The organic layer was washed three times with a $5 \%$ sodium hydrogen carbonate solution $(10 \mathrm{~mL})$, and then dried over anhydrous magnesium sulfate. The solvent was evaporated under reduced pressure to obtain $\mathbf{2}$, at a $58 \%$ yield $(689 \mathrm{mg})$, as a pale yellow syrup.

${ }^{1} \mathrm{H}$ NMR $\left(400 \mathrm{MHz}, \mathrm{CDCl}_{3}\right) \delta 4.15(\mathrm{t}, J=5.8 \mathrm{~Hz}, 2 \mathrm{H}), 2.54(\mathrm{t}, J=5.7 \mathrm{~Hz}, 2 \mathrm{H}), 2.35-2.19(\mathrm{~m}$, $8 \mathrm{H}), 1.67-1.53(\mathrm{~m}, 2 \mathrm{H}), 1.34-1.17(\mathrm{~m}, 24 \mathrm{H}), 0.86(\mathrm{t}, J=6.9 \mathrm{~Hz}, 3 \mathrm{H})$.

Synthesis of palmitoyloxyethyl-N-dodecyl-N,N-dimethylammonium bromide (Es)

The quaternarization was carried out using 1-bromododecane (598 mg. $2.4 \mathrm{mmol})$ and 2 (689 mg, 
$2.1 \mathrm{mmol})$ in anhydrous acetonitrile $(4.3 \mathrm{~mL})$ at $65^{\circ} \mathrm{C}$ for $1 \mathrm{~d}$ with stirring. After the reaction, the solvent was evaporated under reduced pressure. Purification was carried out by recrystallization using ethyl acetate $(120 \mathrm{~mL})$ to obtain Es, at a $44 \%$ yield $(609 \mathrm{mg})$, as a white crystal.

${ }^{1} \mathrm{H}$ NMR (500 MHz, MeOD- $\left.d_{4}\right) \delta 4.54-4.46(\mathrm{~m}, 2 \mathrm{H}), 3.74-3.65(\mathrm{~m}, 2 \mathrm{H}), 3.41-3.34(\mathrm{~m}, 2 \mathrm{H})$, $3.14(\mathrm{~s}, 6 \mathrm{H}), 2.37(\mathrm{t}, J=7.5 \mathrm{~Hz}, 2 \mathrm{H}), 1.85-1.72(\mathrm{~m}, 2 \mathrm{H}), 1.68-1.55(\mathrm{~m}, 2 \mathrm{H}), 1.45-1.20(\mathrm{~m}, 42 \mathrm{H})$, 0.96-0.85 (m, 6H). ESI-MS in acetonitrile $(\mathrm{m} / \mathrm{z}): 496.5094\left[\mathrm{M}-\mathrm{Br}^{-}\right]^{+}$; calcd, $496.5088\left[\mathrm{M}-\mathrm{Br}^{-}\right]^{+}$.

\section{Synthesis of the amphiphile having an amide linkage and an ester linkage (iPrEs)}

iPrEs was synthesized according to the procedure given in Scheme S3.<smiles>CC(C)C(=O)Cl</smiles>

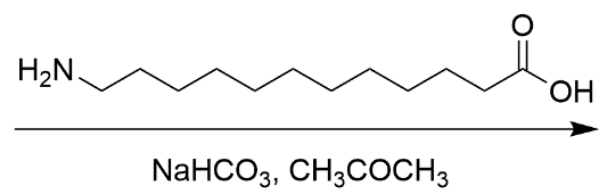<smiles>CC(C)C(=O)NC(=O)O</smiles>

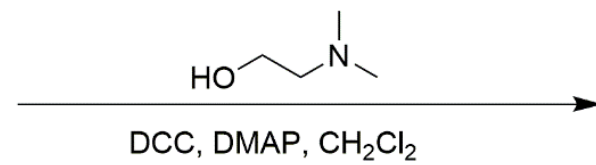<smiles>CC(C)C(=O)NC(=O)OCCN(C)C</smiles>

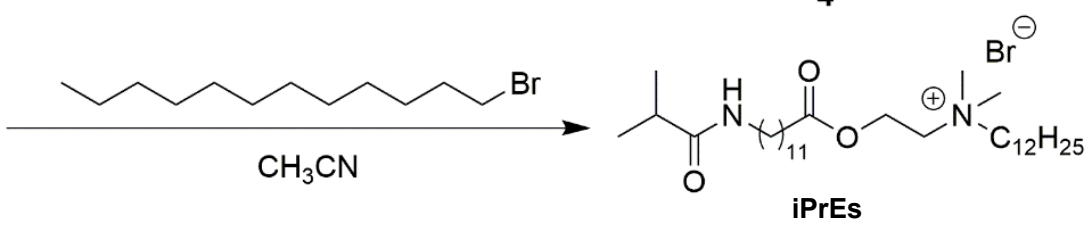

Scheme S3. Synthesis of iPrEs

\section{Synthesis of 12-isobutyramidodecanoic acid (3)}

A mixture of 12-aminododecanoic acid (1.28 g, $6.0 \mathrm{mmol})$, isobutyryl chloride (1.49 g, $12 \mathrm{mmol})$ and sodium hydrogen carbonate $(1.01 \mathrm{~g}, 12 \mathrm{mmol})$ was stirred in anhydrous acetone $(60 \mathrm{~mL})$ at $70{ }^{\circ} \mathrm{C}$ for $2 \mathrm{~h}$. After the reaction, the mixture was poured on chloroform $(30 \mathrm{~mL})$. The organic 
layer was washed three times with water $(50 \mathrm{~mL})$, and then dried over anhydrous magnesium sulfate. After the solvent was evaporated under reduced pressure, the residue was purified by silica gel column chromatography [chloroform/methanol/trimethylamine $=150 / 10 / 1$ (by volume), $\left.R_{\mathrm{f}}=0.24\right]$ to obtain 3 , at a $24 \%$ yield $(405 \mathrm{mg})$, as a white crystal.

${ }^{1} \mathrm{H}$ NMR $\left(500 \mathrm{MHz}, \mathrm{CDCl}_{3}\right) \delta 3.28-3.17(\mathrm{~m}, 2 \mathrm{H}), 2.38-2.28(\mathrm{~m}, 3 \mathrm{H}), 1.68-1.55(\mathrm{~m}, 2 \mathrm{H})$, $1.55-1.42(\mathrm{~m}, 2 \mathrm{H}), 1.40-1.19(\mathrm{~m}, 14 \mathrm{H}), 1.14(\mathrm{t}, J=6.7 \mathrm{~Hz}, 6 \mathrm{H})$.

\section{Synthesis of 12-(isobutyramido)lauroyloxyethyl-N,N-dimethylamine (4)}

A mixture of 3 (228 $\mathrm{mg}, 0.80 \mathrm{mmol})$, 2-dimethylamino ethanol (143 mg, $1.6 \mathrm{mmol})$ and 4dimethylamino pyridine $(5 \mathrm{mg})$ was dissolved in anhydrous dichloromethane $(1.0 \mathrm{~mL})$. At $0{ }^{\circ} \mathrm{C}$, a solution of $N, N^{\prime}$-dicyclohexylcarbodiimide $(206 \mathrm{mg}, 1.0 \mathrm{mmol})$ in dichloromethane $(0.7 \mathrm{~mL})$ was added, and the reaction mixture was stirred at $0{ }^{\circ} \mathrm{C}$ for $30 \mathrm{~min}$ and then at room temperature for $15 \mathrm{~h}$. After the reaction, the precipitate was filtered off, and the solvent was evaporated under reduced pressure. The residue was then purified by silica gel column chromatography [chloroform/methanol/trimethylamine $=100 / 15 / 1$ (by volume), $R_{\mathrm{f}}=0.49$ and 0.17 ] to obtain a mixture containing 4 and the mixture was purified silica gel column chromatography [chloroform/acetone/trimethylamine $=70 / 30 / 1$ (by volume), $R_{\mathrm{f}}=0.09$ ] to obtain 4 , at a $19 \%$ yield ( 53 $\mathrm{mg}$ ), as a white crystal.

${ }^{1} \mathrm{H}$ NMR $\left(500 \mathrm{MHz}, \mathrm{CDCl}_{3}\right) \delta 4.17(\mathrm{t}, J=6.0 \mathrm{~Hz}, 2 \mathrm{H}), 3.27-3.20(\mathrm{~m}, 2 \mathrm{H}), 2.56(\mathrm{t}, J=6.0 \mathrm{~Hz}, 2 \mathrm{H})$, $2.38-2.22(\mathrm{~m}, 9 \mathrm{H}), 1.69-1.55(\mathrm{~m}, 2 \mathrm{H}), 1.54-1.43(\mathrm{~m}, 2 \mathrm{H}), 1.36-1.20(\mathrm{~m}, 14 \mathrm{H}), 1.16(\mathrm{~d}, J=6.9 \mathrm{~Hz}$ $6 \mathrm{H})$.

Synthesis of 12-(isobutyramido)lauroyloxyethyl- $N$-dodecyl-N,N-dimethylammonium bromide (iPrEs) 
The quaternization of 4 ( $53 \mathrm{mg}, 0.15 \mathrm{mmol}$ ) was carried out using 1-bromododecane ( $37 \mathrm{mg} .0 .15$ mmol) in anhydrous acetonitrile $(0.3 \mathrm{~mL})$ at $65{ }^{\circ} \mathrm{C}$ for $15 \mathrm{~h}$ with stirring. After the reaction, the solvent was evaporated under reduced pressure. Purification was carried out by reprecipitation from chloroform $(0.2 \mathrm{~mL})$ and ethyl acetate $(2 \mathrm{~mL})$ to obtain $\operatorname{PPrEs}(86 \mathrm{mg}, 95 \%$ yield $)$ as a pale yellow crystal.

${ }^{1} \mathrm{H}$ NMR (500 MHz, MeOD) $\delta 4.55-4.47(\mathrm{~m}, 2 \mathrm{H}), 3.74-3.64(\mathrm{~m}, 2 \mathrm{H}), 3.43-3.34(\mathrm{~m}, 2 \mathrm{H})$, 3.19-3.05 (m, 8H), 2.47-2.35 (m, 3H), 1.84-1.74 (m, 2H), 1.68-1.56 (m, 2H), 1.53-1.20 (m, 34H), 1.09 (d, $J=7.0 \mathrm{~Hz}, 6 \mathrm{H}), 0.89(\mathrm{t}, J=5.8 \mathrm{~Hz}, 3 \mathrm{H})$. ESI-MS in acetonitrile $(\mathrm{m} / \mathrm{z}): 525.4995$ $\left[\mathrm{M}-\mathrm{Br}^{-}\right]^{+}$. Calcd, $525.4990\left[\mathrm{M}-\mathrm{Br}^{-}\right]^{+}$.

\section{Synthesis of the $N$-(2-hydroxyethyl)- $N$-dodecyldimethylammonium bromide (QA)}

The quaternization was carried out using 1-bromododecane (748 mg. $3.0 \mathrm{mmol}$ ) and $\mathrm{N}, \mathrm{N}$ dimethylaminoethanol $(267 \mathrm{mg}, 3.0 \mathrm{mmol})$ in anhydrous acetonitrile $(3.8 \mathrm{~mL})$ at $65{ }^{\circ} \mathrm{C}$ for $1 \mathrm{~d}$ with stirring. After the reaction, the solvent was evaporated under reduced pressure. Purification was carried out by reprecipitation from chloroform $(1.4 \mathrm{~mL})$ and ethyl acetate $(7 \mathrm{~mL})$ to obtain QA, at a $91 \%$ yield $(921 \mathrm{mg})$, as a white crystal.

${ }^{1} \mathrm{H}$ NMR (500 MHz, MeOD- $\left.d_{4}\right) \delta 4.01-3.94(\mathrm{~m}, 2 \mathrm{H}), 3.48-3.42(\mathrm{~m}, 2 \mathrm{H}), 3.43-3.34(\mathrm{~m}, 2 \mathrm{H})$, $3.14(\mathrm{~s}, 6 \mathrm{H}), 1.84-1.72(\mathrm{~m}, 2 \mathrm{H}), 1.44-1.21(\mathrm{~m}, 18 \mathrm{H}), 0.94-0.85(\mathrm{~m}, 3 \mathrm{H})$. ESI-MS in acetonitrile ( $m / z): 258.2797\left[\mathrm{M}-\mathrm{Br}^{-}\right]^{+}$; calcd, 258.2791 [M - $\left.\mathrm{Br}^{-}\right]^{+}$.

\section{Synthesis of the $N$-dodecyl- $N$-hexadecyl- $N, N$-dimethylammonium bromide (N)}

The quaternarization of $N, N$-dimethyldodecylamine ( $853 \mathrm{mg}, 4.0 \mathrm{mmol})$ was carried out using 1bromohexadecane $(1.22 \mathrm{~g}, 4.0 \mathrm{mmol})$ in anhydrous acetonitrile $(5.0 \mathrm{~mL})$ at $65{ }^{\circ} \mathrm{C}$ for $1 \mathrm{~d}$ with stirring. After the reaction, the solvent was evaporated under reduced pressure. Purification was 
carried out by reprecipitation from chloroform $(2 \mathrm{~mL})$ and ethyl acetate $(10 \mathrm{~mL})$ to obtain $\mathbf{N}$, at a $73 \%$ yield $(1.51 \mathrm{~g})$, as a white crystal.

${ }^{1} \mathrm{H}$ NMR (500 MHz, $\left.\mathrm{CDCl}_{3}\right) \delta 3.58-3.47$ (m, 4H), 3.43 (s, 6H), 1.76-1.62 (m, 4H), 1.42-1.18 (m, 44H), 0.92-0.80 (m, 6H). ESI-MS in acetonitrile $(m / z): 438.5039\left[\mathrm{M}-\mathrm{Br}^{-}\right]^{+}$. calcd, 438.5033 $\left[\mathrm{M}-\mathrm{Br}^{-}\right]^{+}$

Synthesis of $N$-(3', 6'-dihydroxy-3-oxospiro[isobenzofuran-1(3H),9'-[9H]xanthen]-5-yl) - $N^{\prime}-$ dodecylthiourea (F)

Fluorescein isothiocyanate (isomer I) (20 mg, $0.05 \mathrm{mmol})$ and dodecylamine $(9.3 \mathrm{mg}, 0.05 \mathrm{mmol})$ was added to an acetone $(0.6 \mathrm{~mL})$. The reaction mixture was stirred at room temperature for $2 \mathrm{~d}$. The mixture was then concentrated under reduced pressure, and the residue was washed with a 1 $\mathrm{M} \mathrm{HCl}(5 \mathrm{~mL})$ and water $(5 \mathrm{~mL})$ successively. After filtration, $\mathbf{F}$ was obtained, at a $42 \%$ yield $(12$ $\mathrm{mg}$ ) as an orange powder.

${ }^{1} \mathrm{H}$ NMR (500 MHz, methanol- $\left.d_{4}\right) \delta 8.11(\mathrm{~s}, 1 \mathrm{H}), 7.75(\mathrm{~d}, J=7.4 \mathrm{~Hz}, 1 \mathrm{H}), 7.14(\mathrm{~d}, J=8.0 \mathrm{~Hz}$, $1 \mathrm{H}), 6.78-6.61(\mathrm{~m}, 4 \mathrm{H}), 6.54(\mathrm{dd}, J=8.7,2.4 \mathrm{~Hz}, 2 \mathrm{H}), 3.60(\mathrm{~s}, 2 \mathrm{H}), 1.69-1.59(\mathrm{~m}, 2 \mathrm{H}), 1.42-1.18$ $(\mathrm{m}, 18 \mathrm{H}), 0.89(\mathrm{t}, \mathrm{J}=7.0 \mathrm{~Hz}, 3 \mathrm{H})$. 


\section{Figures}
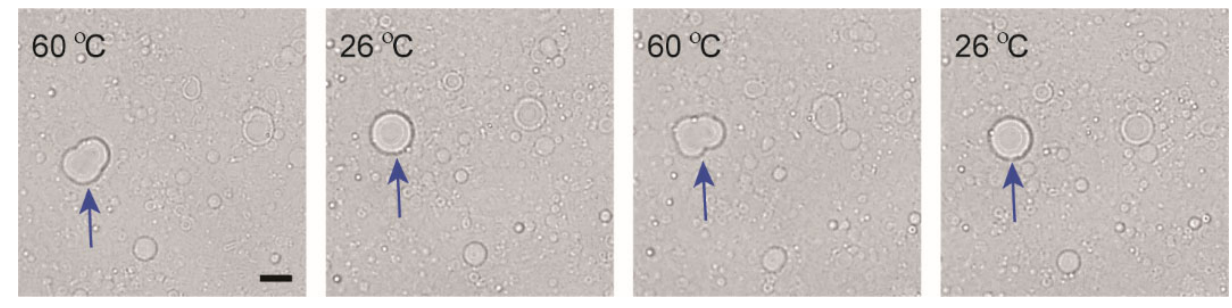

Figure S1. Typical micrographs of the GVs composed of Es $(1 \mathrm{mM})$ and $\mathbf{N}(1 \mathrm{mM})$, after thermal stimulation at $60^{\circ} \mathrm{C}$. The same GVs are indicated by the same blue arrow. Scale bar $=20 \mu \mathrm{m}$. 
a

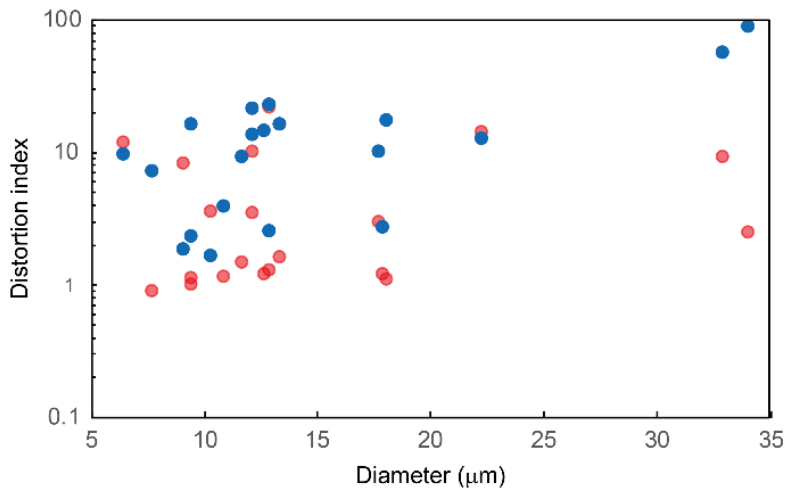

b

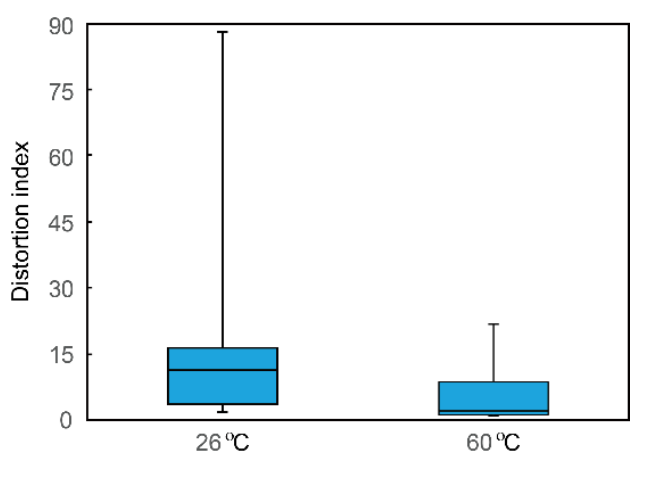

Figure S2. (a) Distortion index $(D)$ of $20 \mathrm{GVs}$ observed at $26^{\circ} \mathrm{C}$ (blue) and $60{ }^{\circ} \mathrm{C}$ (red). The distortion index was defined as $D=l^{2} / S-4 \pi$, where $l$ is the perimeter and $S$ is the area of a GV, respectively, on an image of cross section. ${ }^{2}$ The $\mathrm{GV}$ is a complete sphere when $D$ equals zero. Calculation of the t-test was confirmed that $D$ was significant because the $\mathrm{p}$ value was $<0.05$. (b) Boxplot with whiskers from the minimum to maximum $D$. Box, centerline in box, and whisker indicate 25-75\%, median, and Min-Max, respectively. The depth of focus for the used objective lens was ca. $1 \mu \mathrm{m}$, and there was a statistic difference in $D$ of GVs between the conditions in spite of using the averaged perimeter and cross-sectional area. In addition, the error in the perimeter of spherical GVs from the image analysis, such as setting for threshold of the contour and calculating the actual length from scale bars, was ca. $9 \mu \mathrm{m}$. Considering the propagation of errors, the error in $D$ was estimated to be 0.16 . This indicated that the error was not important for distribution of $D$ of deformed GVs calculated from the current data. From these, the statistical difference in the distortion was more clearly confirmed. 


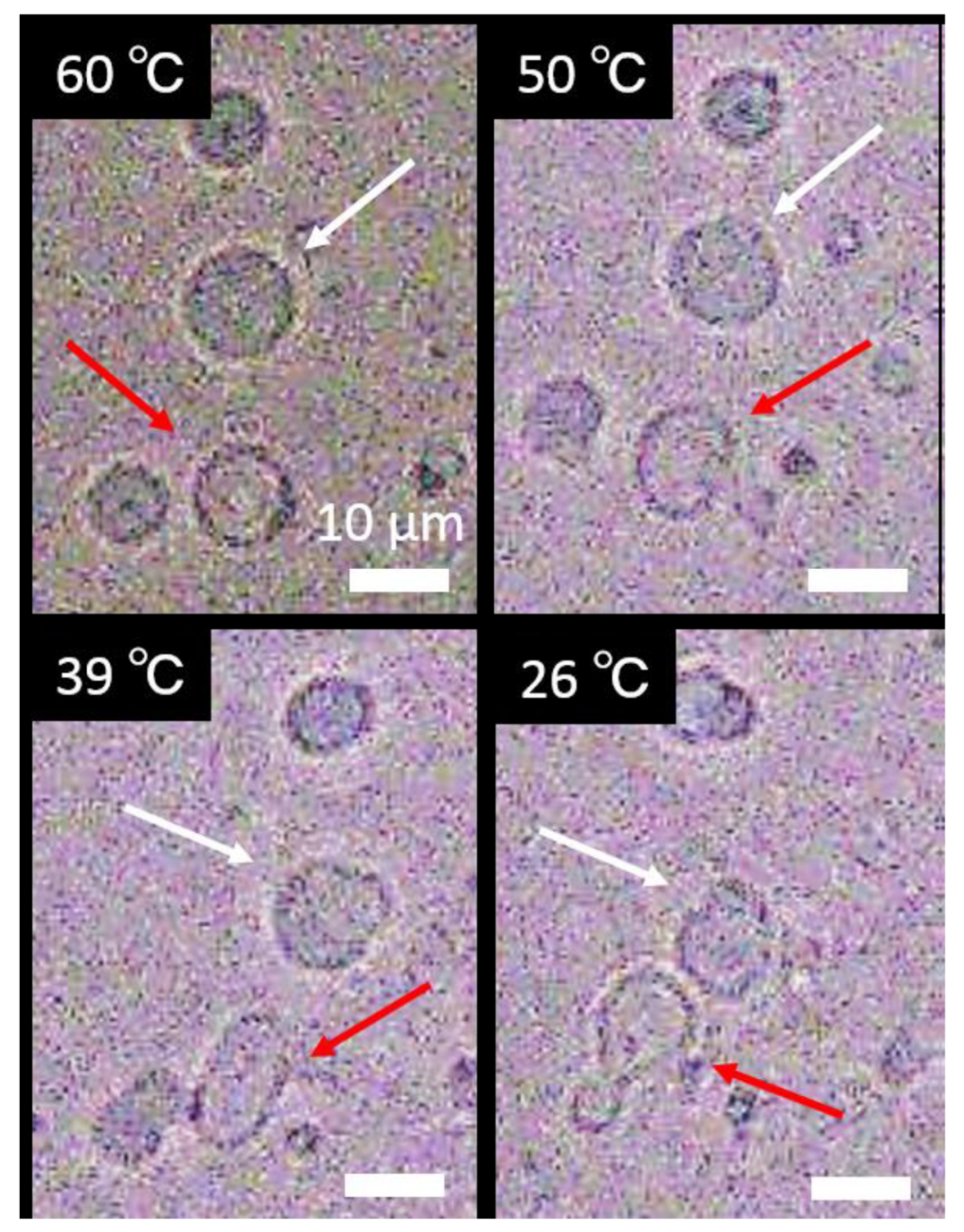

Figure S3. Typical sequential micrographs of GV deformation in the cooling process from 60 to $26^{\circ} \mathrm{C}$. The same GVs are indicated by same colored arrows. GVs deformed not intermittently but continuously. 


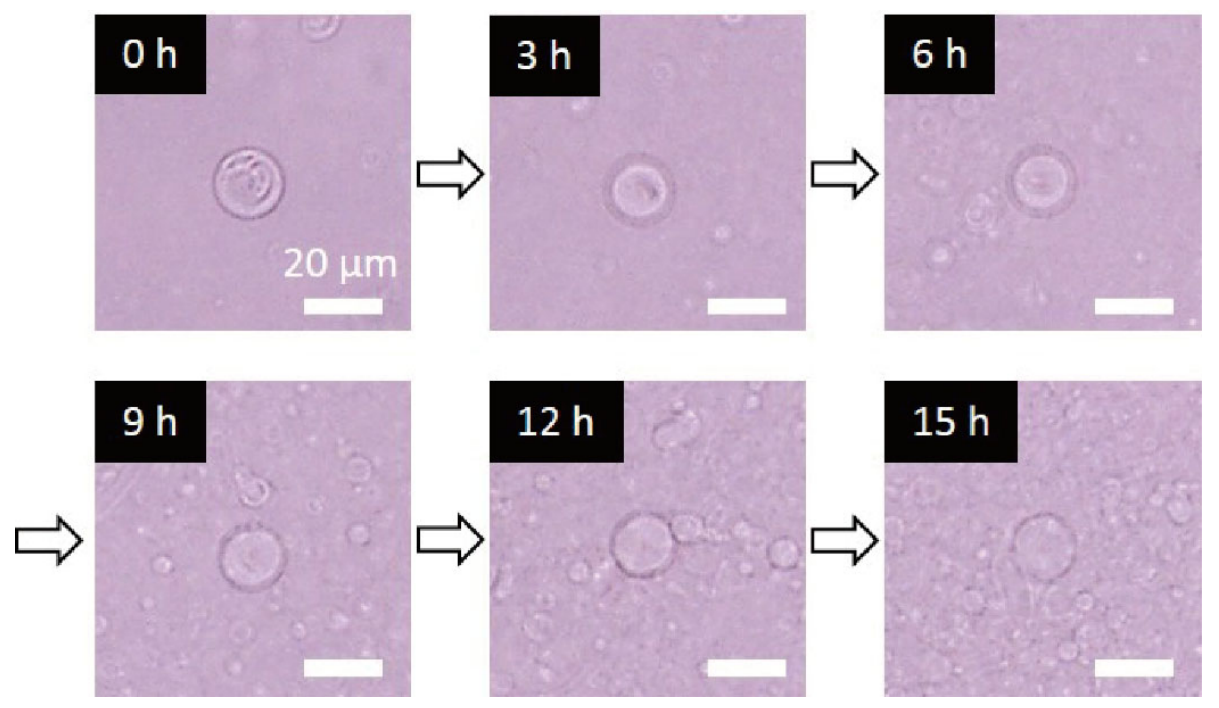

Figure S4. Typical sequential micrographs of the GVs composed of MEs (1 mM) and $\mathbf{N}(1 \mathrm{mM})$ during thermal stimulation at $40{ }^{\circ} \mathrm{C}$.

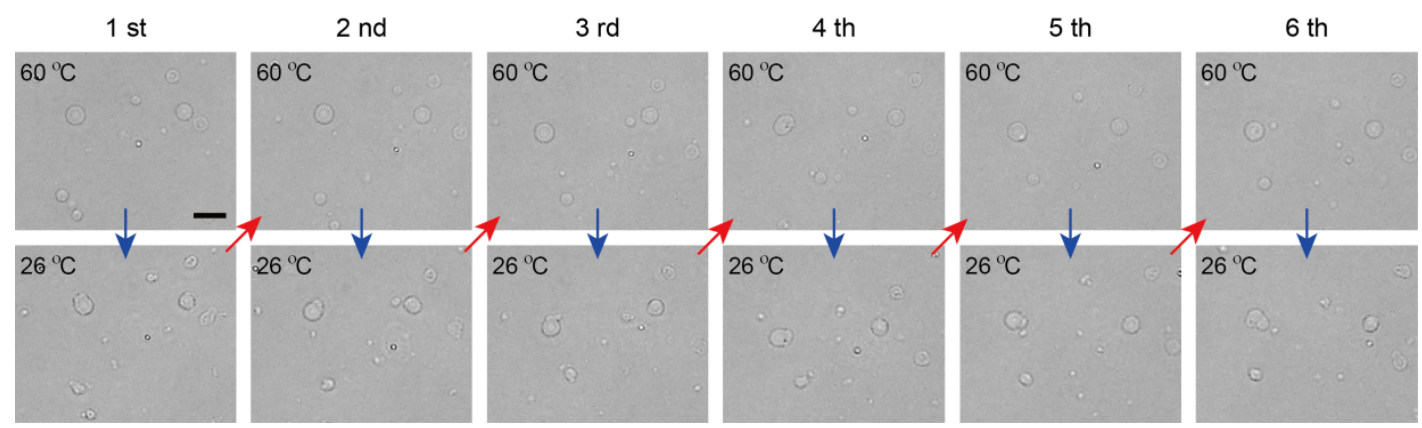

Figure S5. Deformation of the GVs composed of MEs $(1 \mathrm{mM})$ and $\mathbf{N}(1 \mathrm{mM})$ in response to the successive temperature change $\left(30{ }^{\circ} \mathrm{C} / \mathrm{min}\right)$, after the reaction for $15 \mathrm{~h}$ at $60^{\circ} \mathrm{C}$, in the absence of the polymerization initiator. Scale bar $=20 \mu \mathrm{m}$. 

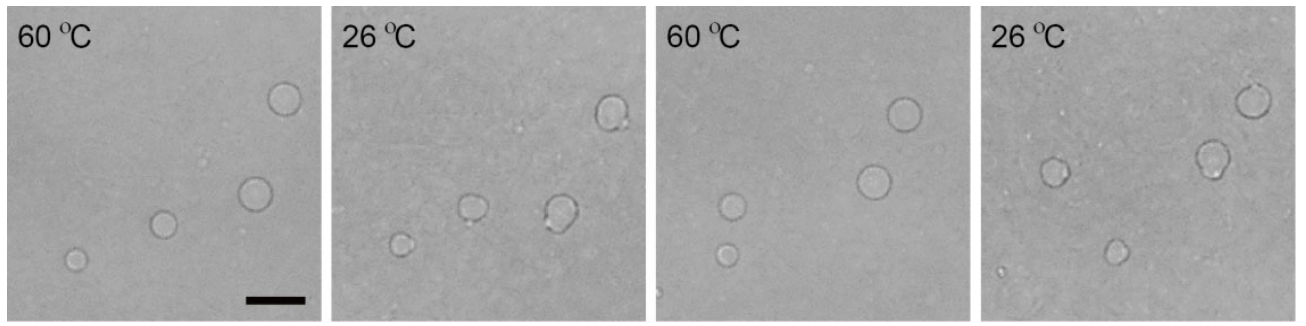

Figure S6. Typical micrographs of the GVs composed of MEs $(1 \mathrm{mM})$ and $\mathbf{N}(1 \mathrm{mM})$, after thermal stimulation at $60{ }^{\circ} \mathrm{C}$, in the presence of a polymerization initiator. Scale bar $=20 \mu \mathrm{m}$.

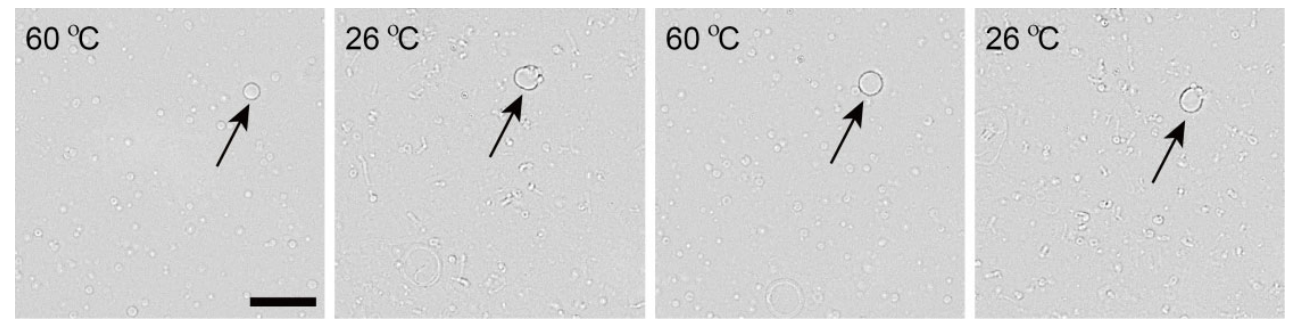

Figure S7. Typical micrographs of the GVs composed of iPrEs $(1 \mathrm{mM})$ and $\mathbf{N}(1 \mathrm{mM})$ after thermal stimulation at $60{ }^{\circ} \mathrm{C}$, in the absence of a polymerization initiator. The same GVs are indicated by the same black arrows. Scale bar $=40 \mu \mathrm{m}$. 


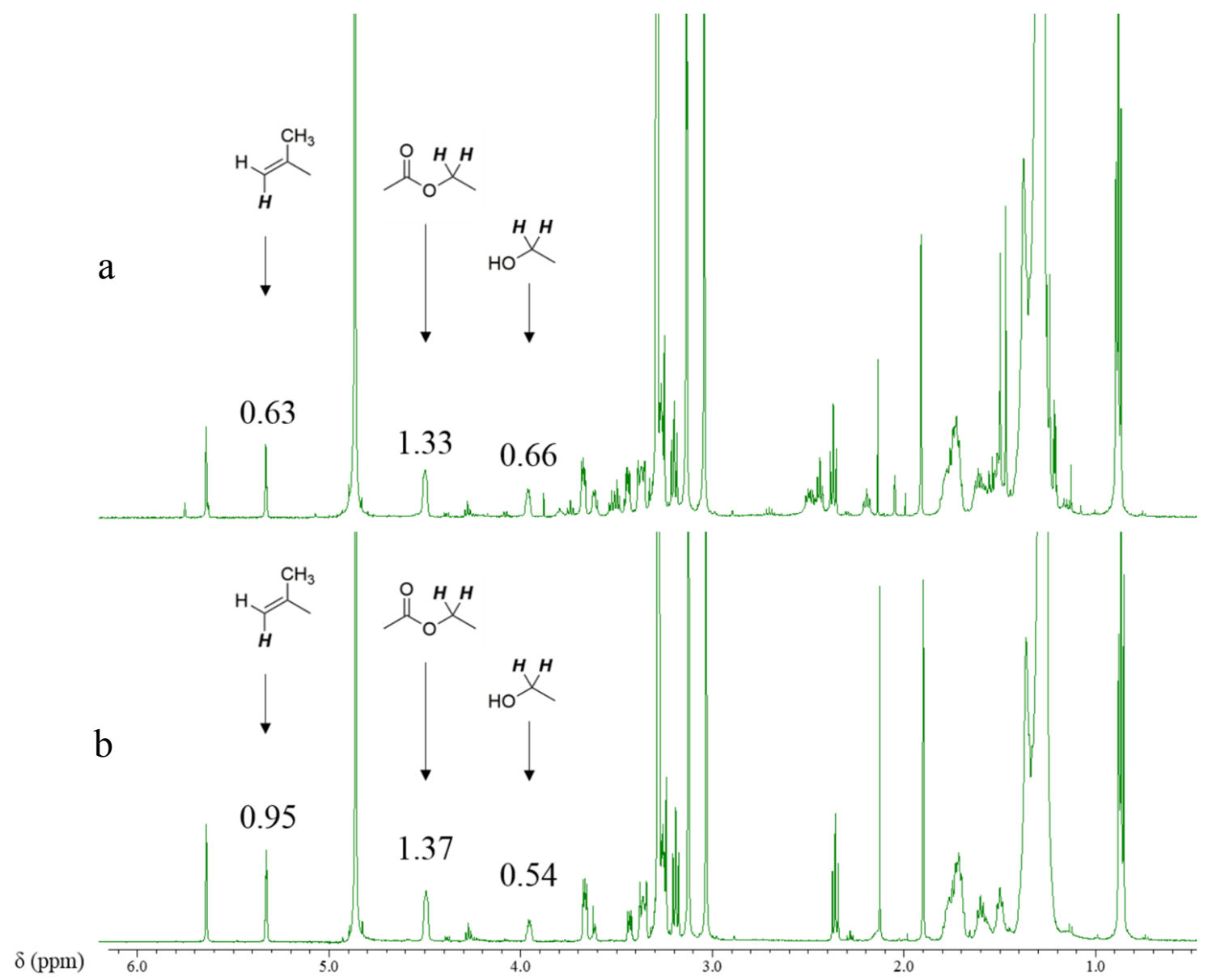

Figure S8. ${ }^{1} \mathrm{H}$ NMR spectra (methanol- $\left.d_{4}\right)$ of the lyophilized samples composed of MEs $(1 \mathrm{mM})$ and $\mathbf{N}(1 \mathrm{mM})$ in an aqueous solution in the presence (a) and absence (b) of the water-soluble polymerization initiator $(0.5 \mathrm{mM})$, after $15 \mathrm{~h}$ at $60^{\circ} \mathrm{C}$. The conversion of the vinyl group and the hydrolytic degradation of the ester were calculated from the integration value of the peaks for the vinyl protons at $\delta 5.35-5.31 \mathrm{ppm}$, and the ratio between the methylene protons adjacent to the ester linkage at $\delta 4.54-4.46 \mathrm{ppm}$ and those adjacent to the hydroxyl group of $\mathbf{Q A}$, at $\delta 3.99-3.93$ ppm, respectively. 

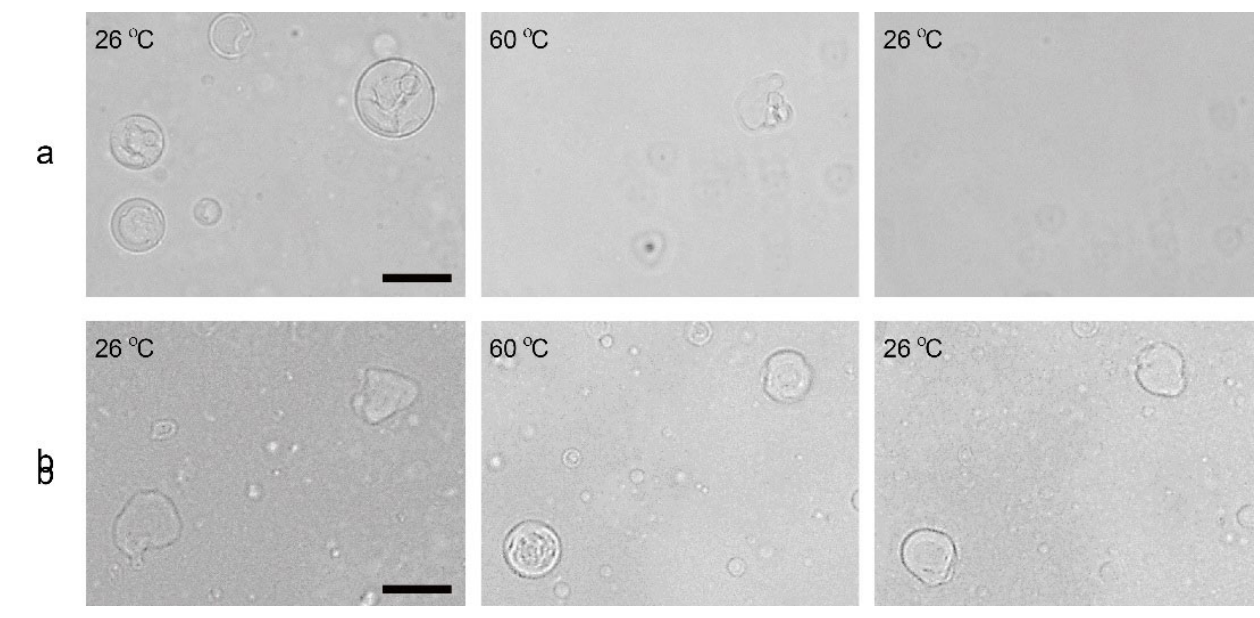

Figure S9. Typical micrographs of the GV morphologies in the dispersion, during the temperature changes between $26^{\circ} \mathrm{C}$ and $60{ }^{\circ} \mathrm{C}$. The temperature change was fixed at $2{ }^{\circ} \mathrm{C} / \mathrm{min}$. The contents of the prepared GV dispersion were MEs:MCar:QA:N $=0.9: 0.1: 0.1: 1.0$ (mM) (a) and 0.7:0.3:0.3:1.0 (mM) (b). Scale bar $=20 \mu \mathrm{m}$.

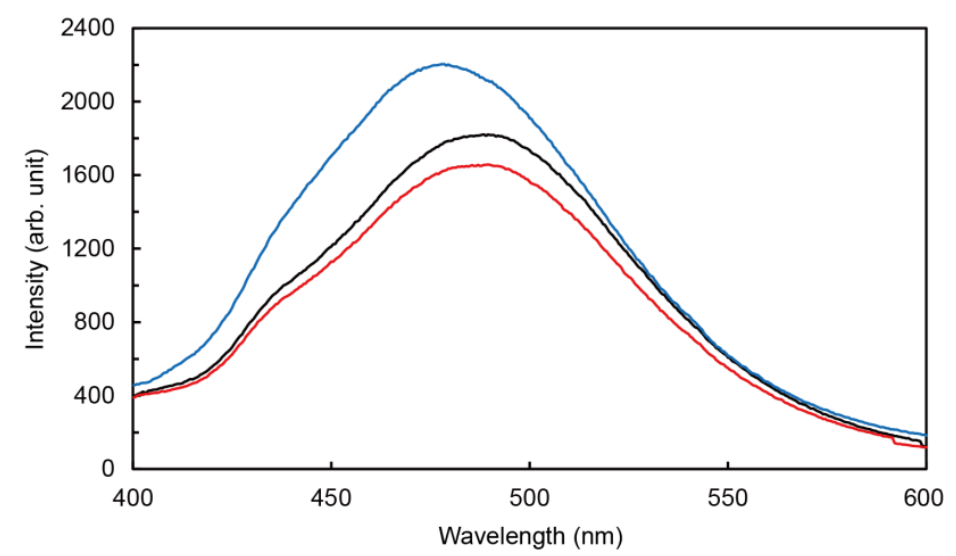

Figure S10. Fluorescence spectra of the vesicle dispersion composed of MEs:N (1.0:1.0 mM) with laurdan after $0 \mathrm{~h}$ (black), $3 \mathrm{~h}$ (red), and $15 \mathrm{~h}$-thermal stimulation (blue). The GP values of the vesicle dispersion were $-0.27,-0.27$, and -0.15 for $0 \mathrm{~h}, 3 \mathrm{~h}$, and $15 \mathrm{~h}$ thermal stimulation, respectively. This result suggests that the vesicle membranes became harder with time under thermal stimulation. 


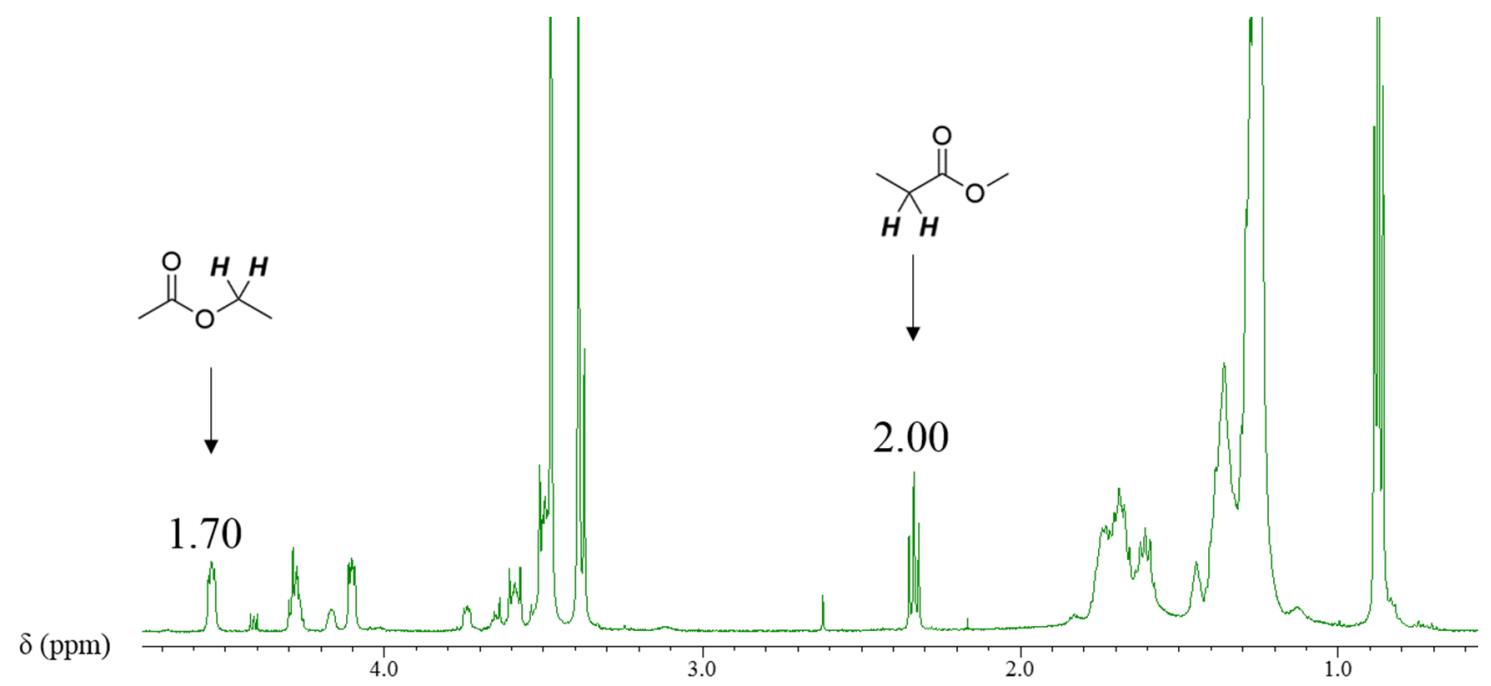

Figure S11. ${ }^{1} \mathrm{H}$ NMR spectrum $\left(\mathrm{CDCl}_{3}\right)$ of the lyophilized samples composed of Es $(1 \mathrm{mM})$ with $\mathbf{N}(1 \mathrm{mM})$ in an aqueous solution at $60{ }^{\circ} \mathrm{C}$ for $15 \mathrm{~h}$. The sample of the reaction mixture was examined at $15 \mathrm{~h}$ after the dispersion was heated to $60{ }^{\circ} \mathrm{C}$. The hydrolytic degradation of the ester was calculated from the integration value of the peaks of the methylene protons adjacent to the ester linkage of Es at $\delta 4.58-4.50 \mathrm{ppm}$, and the methylene protons adjacent to the carbonyl group of Es and palmitic acid (Car) at $\delta 2.39-2.29 \mathrm{ppm}$. 


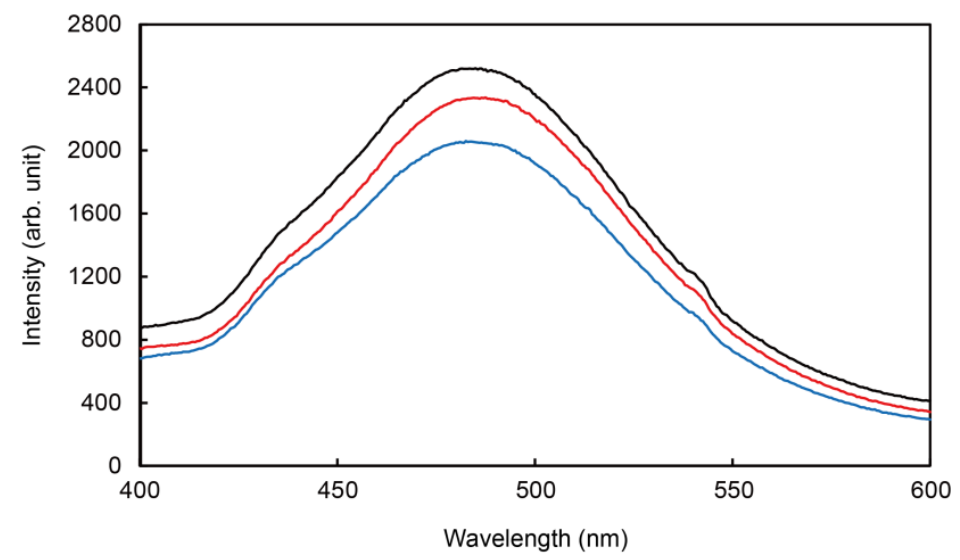

Figure S12. Fluorescence spectra of the vesicle dispersion composed of Es:N $=1.0: 1.0 \mathrm{mM}$ (black), Es:QA:Car:N $=0.9: 0.1: 0.1: 1.0 \mathrm{mM}$ (red), and Es:QA:Car:N $=0.7: 0.3: 0.3: 1.0 \mathrm{mM}$ (blue). The GP values of the vesicle dispersion containing 0,10 , and $30 \mathrm{~mol} \%$ hydrolyzed products of Es were $-0.23,-0.26$, and -0.23 , respectively. 


\section{Table}

Table S1. Conversion of ester and vinyl groups in MEs without the initiator at $60{ }^{\circ} \mathrm{C}$.

\begin{tabular}{|c|c|c|}
\hline Time & Hydrolysis of ester, \% & Polymerization of vinyl, \% \\
\hline $3 \mathrm{~h}$ & 10 & 3 \\
\hline $15 \mathrm{~h}$ & 28 & 5 \\
\hline
\end{tabular}

\section{Reference}

1. Banno, T.; Kazayama, Y.; Toyota, T. Giant Vesicle Formation of Novel Polymerizable Amphiphile Associated with Its Polymerization and Hydrolysis in Water. Chem. Lett. 2014, 43, 1707-1709.

2. Tomita, T.; Sugawara, T.; Wakamoto, Y. Multitude of Morphological Dynamics of Giant Multilamellar Vesicles in Regulated Nonequilibrium Environments. Langmuir 2011, 27, 10106-10112. 